\title{
The Role and Tasks of Civil Society Institutions in Ensuring National Security and Countering Modern Threats and Challenges
}

\author{
Submitted 06/06/20, $1^{\text {st }}$ revision 16/07/20, $2^{\text {nd }}$ revision 26/08/20, accepted 15/09/20 \\ A.M. Voronov ${ }^{1}$, M.N. Kobzar-Frolova ${ }^{2}$, R.N. Lapidus ${ }^{3}$, A.I. Samsonov ${ }^{4}$,
}

\begin{abstract}
:
Purpose: Nowadays, not only the Russian Federation, but also the whole world is facing threats and challenges different from political and economic ones. The COVID-19 pandemic is raging in the world. The purpose of the article is to identify the role and tasks of civil society institutions in ensuring national security and countering threats and challenges of our time.

Design/Methodology/Approach: The authors rely upon the fact that despite all the efforts made by the government of the Russian Federation, federal state bodies, and local selfgovernment bodies, it is necessary to consolidate the entire society and all the public institutions in the face of real threats and challenges of our time. Relevant is the need to reveal the features, the essence, internal relations and the correlation of the state policy and civil society institutions in conditions of real threats to national security and countering the challenges of modernity, to identify the role and tasks of civil society institutions in ensuring national security and countering threats and challenges of modernity.

Findings: The authors point out that not only measures taken by the government of the Russian Federation can counteract security threats, but also clear interaction of all the state structures together with civil society institutions. The participation of citizens in the projects of the Russian Federation and local self-government bodies is a form of close connection of the people with the state, the manifestation of the democracy. The article presents the author's concept of civil society, lists security threats in the field of health care, and suggests possible variants of this interaction.

Practical Implications: The authors propose to adopt a new Federal law of the Russian Federation "On the promotion of civil society institutions in ensuring national security". According to the authors, civil society is the reserve that the state can use in ensuring national security and countering threats and challenges of our time.
\end{abstract}

1 Doctor in Law, Professor, Chief Researcher of the Research Center, Academy of Management of the Ministry of Internal Affairs of Russia, Moscow, Russian Federation, Alex_voronoff@mail.ru

${ }^{2}$ Doctor in Law, Professor, chief researcher of the Institute of State and Law of the Russia's Academy of Sciences, Moscow, Russian Federation, adminlaw@igpran.ru

${ }^{3}$ applicant of the Institute of State and Law of the Russia's Academy of Sciences, Moscow, 119019, Russian Federation, adminlaw@igpran.ru

${ }^{4}$ applicant of the Institute of State and Law, Russia's Academy of Sciences; The head of the direction "Legal factors of the economic development, ANO "Vnesheconombank" Moscow, Russian Federation, 1079966 ai.samsonov@mail.ru 
Originality/Value: The authors rethink the role of civil society in countering modern threats and challenges. Ehe development of the non-state security system is the reserve of the state that's not fully used by society today for countering threats and challenges of our time.

Keywords: Civil society, civil society institutions, national security, protection and security, counteraction, challenges and threats, covid-19 pandemic.

JEL codes:

Paper type: Research article.

\section{Introduction}

The Russian Federation is one of the world's leading powers with its own centuriesold history, traditions, developed system of normative legal acts, democratic institutions, defending the interests of federalism, protecting its constitutional system, sovereignty, and identity from external and internal challenges. In the current turbulent period in relations with foreign countries, the Russian Federation pursues its independent policy for ensuring state protection and national security, takes effective measures for strengthening the state system. The real value of this protection is that it presents the society civilisation level and makes true the principle of ensuring human and civil rights and freedoms, which, according to the Constitution of the Russian Federation, are the highest value of the state (art. 2).

Russia has created a stable basis for its further economic, political and moral potential. The country has demonstrated its ability to defend and protect its interests in the international arena, to counter external threats and challenges in conditions of antiRussian sanctions imposed by the United States and the European Union and aimed at undermining the Russia's economic and political system. Violating the norms of international law and striving to retain their dominance in the whole world, the United States and its NATO allies have taken a course aimed at weakening the Russia's position in the CIS and discrediting Russia's state institutions.

Meanwhile, Russia has consistently achieved authority and stability in the international arena, using historically proven techniques and methods: diplomacy, negotiating and reaching agreements based on the principles of international law, supporting countries in need, ensuring reliable and equal security of states, mutual respect for peoples, and an active integration policy. Moreover, Russia constantly consolidates civil society on the base of common values forming the foundation of humanism, aimed at peace between nations and unity of cultures, etc.

To prevent threats to national security, the Russian Federation has focused its efforts on strengthening internal unity, enhancing the role and the importance of civil society and its institutions in state affairs, and ensuring social stability, harmony, tolerance and respect for traditions. In order to protect national interests, Russia pursues an open, rational, and pragmatic foreign policy that excludes costly confrontation (including a new arms race). 
The purpose of the article is to identify the role and tasks of civil society institutions in ensuring national security and countering threats and challenges of our time. The tasks of the article are: to analyse the legal regulation between state bodies, local selfgovernment bodies and civil society institutions, to identify in the Russian Federation the links "state - public authorities - civil society - national security", to prove that civil society is the reserve that can be fully used by the state in case of threats and challenges of modern times, to draw conclusions relevant to the study.

The research object is public relations connected with the participation of civil society in ensuring national security and countering threats and challenges of our time.

\section{Materials and Methods}

Theoretical basis of the article is fundamental works of the researchers in the field of general theory of law, administrative law and state governance about national security such as A.M. Voronov (2007), A.F. Galuzin (2011), M.N. Kobzar-Frolova (2020), A.F. Nozdrachev (2018), S.E. Proletnikova, B.A. Bykov (2019), N.I. Matuzov (2003) and others.

The analysis has shown that despite all the efforts made by the government of the Russian Federation, federal state bodies, and local self-government bodies, it is necessary to consolidate the entire society and all the public institutions in the face of real threats and challenges of our time.

\section{Methodology}

To achieve this goal, we used logical, analytical, comparative-legal, and dialectical methods, synthesis methods. This allow to reveal the features, the essence, internal relations and the correlation of the state policy and civil society institutions in conditions of real threats to national security and countering the challenges of modernity, to identify the role and tasks of civil society institutions in ensuring national security and countering threats and challenges of modernity.

\section{Results}

The authors conclude that the participation of citizens in the implementation of the state projects of the Russian Federation and local self-government bodies is a form of close connection between the people and the state, the manifestation of democracy. In this regard, it is necessary to rethink the role of civil society in countering modern threats and challenges.

The authors present the concept of "civil society", categorize security threats in the field of health care, and suggest possible options for interaction between state bodies and civil society institutions, propose to adopt the new Federal law of the Russian 
Federation "On the assistance of civil society institutions in ensuring national security". The authors concluded that civil society is the reserve that the state can use in order to ensure national security and counter threats and challenges of our time (Voronov et al., 2019).

\section{Legal Regulation and the Theoretical Concept of National Security}

The concept of "national security of the Russian Federation" (hereinafter - national security) is very important for society, its life and evolution.

The main idea of this concept is in the fact that it covers both the defence of the country and all the types of security provided for by the Constitution of the Russian Federation and the legislation of the Russian Federation. It includes: state, public, information, environmental, economic, epidemiological, energy security, as well as personal security. This concept is enshrined in the Decree of the President of the Russian Federation from 31.12.2015 No. 683 "On the National Security Strategy of the Russian Federation" (hereinafter - the Strategy - 2015).

As the President of the Russian Federation suggests national security should be understood as the protection of the people, society and the state from internal and external threats that ensures the implementation of constitutional rights and freedoms of citizens, the decent standard of their life, sovereignty, independence, state and territorial integrity, and the sustainable socio-economic development of the Russian Federation.

Strategy-2015 is a long-term large-scale plan that defines national interests, priorities, goals, tasks and measures in the field of internal and foreign policy aimed at strengthening the national security of the Russian Federation and ensuring its sustainable development in the long term. The provisions of the Strategy-2015 are immanent to the norms of Federal laws No. 390-FL "On security" from December 28, 2010 and No. 172-FL "On strategic planning in the Russian Federation" from June 28, 2014., as well as other Federal laws and acts of the President of the Russian Federation in this area.

Strategy-2015 not only specifies the norms of these laws, but also gives them a purposeful vector for further development, consolidates forces and actions of Federal government bodies, state bodies of the Russian Federation, local self-government bodies, and civil society institutions to create favourable conditions that contribute to the implementation of national goals and strategic national priorities of the Russian Federation. Strategy-2015 is the basis for the formation and the implementation of state policy in the field of national security of the Russian Federation, the inseparable relationship between the national security and the socio-economic development of the country. The adoption of the Economic Security Strategy of the Russian Federation for the period up to 2030 in 2017 was a logical continuation of the course in terms of 
implementing the strategic national priorities set by the President of the Russian Federation in the field of security.

According to experts, by decree No. 208 from May 13, 2017, the President of the Russian Federation set a number of new systemic tasks for state authorities of various levels and local self-government bodies, which significantly contributed to the concentration of security measures in the economy (Proletenkova and Bykov, 2019).

On the other hand, the same experts argue that linking protection to security needs to determine the relationship between the concepts of "danger - security" and "security as protection from danger". This is due to the fact that the security concept is not a concept "in itself", it exists not in isolation, but serves as a response to a real threat (danger). It has not only theoretical, but also practical meaning, since administrative and legal conceptions of security types are based on the "security as protection from danger" paradigm. In accordance with these conceptions, systems and tools are created to ensure security against external and internal threats (hazards) (Proletenkova and Bykov, 2019).

It should be admitted, the President of the Russian Federation has created a Council for the development of civil society and human rights. Its main purpose is to be an advisory body in the following matters: assisting the head of state in the realisation of his constitutional powers in the field of ensuring and protecting human and civil rights and freedoms and informing about affairs in this field; promoting the development of civil society institutions in the Russian Federation; preparing proposals to the head of state on issues within the competence of the Council.

\section{Relevance}

In 2020, not only the Russian Federation but also the whole world faced threats and challenges different from political and economic ones. The cataclysms of modern society have deep roots. First of all, these are environmental problems. The results of scientific and technological progress determined by the so-called fourth industrial revolution have affected the global climate. Our planet is threatened by global warming. The imbalance of the multipolar world that led to the arms race, the creation of not only nuclear, but also biological, and perhaps epidemiological weapons, pose a real threat to the security of the whole world society. The coronavirus pandemic ${ }^{5}$ is raging in the world, including Russia. The huge numbers of infected persons, patients with coronavirus, and thousands of human deaths indicate a serious global epidemiological problem. In this regard, strict quarantine measures necessary and mandatory for all the persons have been introduced all over the world.

${ }^{5}$ Note: "Pandemic" (Greek. $\pi \alpha v \delta \eta \mu i \alpha$ "all the people") is an unusually strong epidemic that has spread not locally, but also on the territories of countries and continents; the highest degree of the epidemic process within the entire world society (BME, 1982). 
In this emergency, not only civil society institutions play an important role, but also the activity of volunteers who, in coordination with state and local authorities, form various social movements to combat the coronavirus pandemic. Volunteers are public representatives are doing a hell of an explanatory work with citizens who do not observe the regime of self-isolation, in order to avoid violations of the recommendations, bans and restrictions temporarily imposed in order to prevent mass diseases. Performing their civic duty on a free basis, they help old neighbours to buy food, to walk with their pets. These and other socially significant actions present the patriotism of the Russian society and assist law enforcement agencies in ensuring the protection of life, health, sanitary well-being and calmness of citizens and society as a whole. All this forces to rethink the role of civil society in countering threats and ensuring national security, including countering threats in the health care sector.

\section{The Concept of Civil Society and its Role in Ensuring National Security and Preventing Threats in the Health Care System}

Civil society is a unity of citizens of the state and their non-profit associations that build relations with the state based on legality, democracy, ensuring a balance of public and private interests, protecting the rights and interests of individuals and members of society in all the spheres of public life. In the National Security Strategy of the Russian Federation-2015, the President of the Russian Federation paid special attention to the health care, strengthening health of the nation as the most important direction of ensuring national security. The implementation of measures in the field of health care is ensured through the implementation of a long-term state policy for the protection of citizens' health. Its key goals and targets are: increasing life expectancy, reducing population mortality, improving the availability and quality of medical care, as well as the vertical system of quality control, effectiveness and safety of medicines, observing citizens' rights in the field of health protection and ensuring state guarantees related to these rights, etc., (Kobzar-Frolova, 2020).

The threats to national security in the sphere of health care identified in 2015 have become real today. The Strategy-2015 as a threat to national security in the sphere of public health includes epidemics and pandemics, the mass spread of diseases, HIV infection, drug and alcohol abuse, etc. At the same time, the President of the Russian Federation recognizes that the factors that negatively affect national security in the sphere of public health protection are shortcomings in the implementation of state health policy in terms of providing affordable and high-quality medical care, the imperfect current health insurance system, insufficient financing of the system of high-tech medical care, etc. These are the issues that have to be urgently solved in the context of the COVID-19 pandemic, not only by the Russian government, but also by the ruling structures of all the countries where this threat is rampant (Khan et al., 2020: Grima et al., 2020).

At the same time, it is important to note that not only measures taken by the government of the Russian Federation, state bodies of constituent entities of the 
Russian Federation, and local self-government bodies can counteract threats in the health care sector, but also clear interaction of all the state structures with civil society institutions. In particular, this interaction will ensure to:

- implement the guarantees of free medical care declared in the Constitution of the Russian Federation;

- provide the sustainability of the mandatory health insurance system;

- improve the effectiveness of regulatory and legal regulation in healthcare and medical services;

- control the quality of work of medical organizations, the quality of manufactured medicines: the compliance with the standards and common criteria for the work of medical institutions;

- develop preventive medicine and primary health care institutions in every possible way and improve its effectiveness;

- improve and implement innovative methods of diagnosis, prevention and treatment, create the basis for personalized medicine;

- introduce modern information and communication techniques in healthcare;

- increase the level of competitiveness of Russia's healthcare in the world market;

- and so on.

It is reasonable to say that in recent years the main vector of activity and selforganization of civil society is aimed at ensuring a balance of public and private interests, interaction between government bodies, strengthening public values, harmony, tolerance, etc. In this regard, it is obvious that the role and the participation of civil society in the development of the country is steadily increasing.

Public control in all the spheres of public life, from the control of management decisions and the final informing all the members of society about these decisions, is one of the most significant formats of this participation. As never before, a new conceptual approach, style and standards of the civil society participation in the country's life are gradually being formed - from public control to active participation. The purpose of such participation is to involve representatives of civil society in the development of strategic projects and to carry out step-by-step monitoring of their implementation. Making the most important state decisions should involve experts from the society, first of all from scientists and practitioners (Noja and Cristea, 2018).

The main task in improving the public control is to strengthen feedback between state (municipal) authorities, citizens and their associations, which mediates an increase in the level of public confidence in decisions taken at the state (municipal) level.

According to a fair opinion of A.F. Nozdrachev (2018), the state apparatus cannot function normally without control. Democracy, proclaimed as the Foundation of Russian statehood, implies the active participation of citizens in politics, in public administration, and in the confidence that the state is for the people, and not the people 
are for the state. Achieving the main goals set in the May decrees of the President of the Russian Federation and in the plans of the government of the Russian Federation, improving the effectiveness of executive bodies is impossible without ensuring their real openness and accessibility to citizens and their associations, and effective interaction with civil society institutions. At the same time, we wholly agree with the fundamentally important conclusion made by A.F. Nozdrachev (2018) that the science of administrative law has not realized all the threats and challenges of the time yet. The contribution of the administrative law science to the cooperation of civil society and the state are considered to be in two aspects. Firstly, it is necessary to substantiate the theoretical prerequisites, outline the conceptual directions and suggest practical forms and methods of the cooperation. Secondly, it is necessary to reconsider issues of interaction between the state and civil society in the administrative law science. In this regard, determining the vector of the development and the counteraction to threats and challenges to national security, it is necessary to modernize (update) legal regulation, in particular, sectoral administrative and legal regulation in the context of the activity of civil society institutions in the field of national security.

According to the final report of the Public chamber of the Russian Federation in 2019 at the Moscow forum the involvement of every active and responsible citizen is a criterion for the success of strategic initiatives, and the formation of a kind of "responsible class" around the national development agenda is the key to value consolidation, the efficiency of political institutions and social optimism (PC RF, 2019). The following main guidelines for civic engagement and new priorities for the dialogue between society, government, and business in 2020 were developed at the Moscow forum:

- public monitoring of the national projects and programs implementation;

- reducing administrative and regulatory barriers;

- monitoring of legislation, as well as monitoring of the level and quality of the non-profit sector development;

- search for new mechanisms to support socially significant initiatives and projects in the framework of corporate social responsibility programs, etc.

The participation of citizens in the governmental projects of the Russian Federation and local self-government bodies is a form of close connection between the people and the state, the manifestation of the foundations of democracy. Accordingly, the involvement of citizens and their associations in the process of state influence on society has always been considered by the administrative law science as an important component of the administrative and legal status of a citizen. Ensuring the participation of civil society in the state affairs creates a link between the executive power and each individual citizen, affects the openness and interaction of democratic institutions, focuses on the support of power by society, helps to prevent conflicts in public relations, etc. In these conditions, a broad constructive public discussion on the values and priorities for the majority of the population is necessary. The authors make a conclusion that the adoption of the Federal law of the Russian Federation "On 
assistance of civil society institutions in ensuring national security" will be one of the factors of consolidation of the state and civil society institutions in ensuring national security. To substantiate their position on the adoption of this Federal law the authors use the following arguments:

- the first argument: the law will give legitimacy and legal basis to civil society institutions;

- the second argument: due to the law it will be possible to disclose and unify the content of definitions such as "danger - security", "security as protection from danger»;

- the third argument: it will legislate concepts such as "non-state system for ensuring national security", "public law enforcement" and so on important both for science and law enforcement practice.

Moreover, this law will define the essence, content, forms and methods of the activity of civil society institutions aimed at ensuring national security, which are based on the motivations such as: adherence to civil duty, tolerance, consolidation of civil society, etc. At the same time, the law will be aimed at developing the system of public control and the moral and ethical responsibility of citizens.

According to the authors, it is the development of the non-state security system that we see as the reserve of the state and which is not fully used by society today for countering threats and challenges of our time.

\section{References:}

Alekseyev, S.S. 1995. Fundamentals of legal policy in Russia: course of lectures. Moscow BMG. 1982. Big medical encyclopaedia. Soviet encyclopaedia series, 18.

Galuzin, A.F. 2008. Legal security and its principles. Saint Petersburg.

Galuzin, A.F. 2011. Legal security in the system of legal policy. Issues of Economics and Law, 1, 347-353.

Grima, S., Dalli Gonzi, R., Thalassinos, I.E. 2020. The Impact of COVID-19 on Malta and its Economy and Sustainable Strategies. Available at SSRN: https://ssrn.com/abstract=3644833 or http://dx.doi.org/10.2139/ssrn.3644833

Khan, S., Rabbani, R.M., Thalassinos, I.E., Atif, M. 2020. Corona Virus Pandemic Paving Ways to Next Generation of Learning and Teaching: Futuristic Cloud Based Educational Model. Available at SSRN: https://ssrn.com/abstract=3669832.

Kobzar-Frolova, M.N. 2020. On the issue of the essence and content of the concept of "safety" in the field of health care. Modern science, Series "Economics and law", 2, 95-101.

Kobzar-Frolova, M.N., Frolov, V.A. 2014. Ensuring security in the field of customs. Bulletin of Perm State University, 4, 43-49.

Matuzov, N.I. 2003. Actual problems of the theory of law. Saratov, 318-319

Matuzov, N.I., Malko, A.V. 1996. Legal regimes: Issues of theory and practice. Jurisprudence, 1.

Noja, G.G., Cristea, M. 2018. Flexicurity Measures as Key Drivers of Economic Growth Empirical Evidence for Europe. Ekonomicky Casopis, 66(7), 719-749. 
Nozdrachev, A.F. 2018. To the $25^{\text {th }}$ anniversary of the Constitution of the Russian Federation. Citizen and Executive power: constitutional bases of relations. Administrative law and process, 12, 21-30.

PC RF. 2019. Report of the Public chamber of the Russian Federation "On the state of civil society for 2019». Available online: https://report2019.oprf.ru/index.html

Proletenkova, S.E., Bykov B.A. 2019. Strategy of economic security of the Russian Federation for the period up to 2030: analysis, efficiency, prospects. Administrative law and process, 8, 36-39.

Voronov, A.M. 2007. Issues of theory and practice of ensuring public security of the Russian Federation. Publishing house of All-Russian state tax academy, Moscow, 2007.

Voronov, A.M., Kobzar-Frolova, M.N., Redkous, V.M. 2019. Civil Society of Modern Russia: Problems of Implementation of Constitutional Rights and Freedoms. International Journal of Economic and Business Administration, 1(7). 